\title{
How many species of goliath grouper are there? Cryptic genetic divergence in a threatened marine fish and the resurrection of a geopolitical species
}

\author{
M. T. Craig ${ }^{1, *}$, R. T. Graham ${ }^{2}$, R. A. Torres ${ }^{3}$, J. R. Hyde ${ }^{4}$, M. O. Freitas ${ }^{5}$, \\ B. P. Ferreira ${ }^{6}$, M. Hostim-Silva ${ }^{7}$, L. C. Gerhardinger ${ }^{8}$, A. A. Bertoncini ${ }^{9}$, \\ D. R. Robertson ${ }^{10}$
}

\begin{abstract}
${ }^{1}$ Hawaii Institute of Marine Biology, University of Hawaii at Manoa, PO Box 1346, Kaneohe, Hawaii 96744, USA
${ }^{2}$ Wildlife Conservation Society, Black Orchid Street, PO Box 37, Punta Gorda, Belize

${ }^{3}$ Laboratório de Genômica Evolutiva e Ambiental, Departamento de Zoologia, Universidade Federal de Pernambuco (UFPE), Av. Prof. Moraes Rego, 1235-Cidade Universitária, Recife, Pernambuco 50670-420, Brazil

${ }^{4}$ Southwest Fisheries Science Center, NMFS, 8604 La Jolla Shores Dr., La Jolla, California 92037, USA

${ }^{5}$ Universidade Estadual de Santa Cruz (UESC), Programa de Pós-Graduação em Sistemas Aquáticos Tropicais, Rodovia Ilhéus-Itabuna km 16, CP 110, Salobrinho, Ilhéus, Bahia 45650-000, Brazil

${ }^{6}$ Universidade Federal de Pernambuco (UEPE), Av. Prof. Moraes Rego, 1235-Cidade Universitária, Recife, Pernambuco 50740-550, Brazil

${ }^{7}$ Universidade do Vale do Itajaí (UNIVALI), CTTMar - Laboratório de Ciências Ambientais, Rua Uruguai 458, Centro Caixa Postal 360, Itajaí, Santa Catarina 88302-202, Brazil

${ }^{8}$ ECOMAR NGO, Multi-Institutional Program on Local Knowledge and Practices, Caravelas, Bahia, Brazil

${ }^{9}$ Universidade Federal de São Carlos (UFSCar), PPGERN, CxP.676 São Carlos, San Paulo 13565-905, Brazil

${ }^{10}$ Smithsonian Tropical Research Institute, Balboa, Republic of Panamá. Mailing address: STRI, Unit 0948, APO AA 34002, USA
\end{abstract}

\begin{abstract}
The goliath grouper Epinephelus itajara (Epinephelidae) is an exceptionally large marine fish that inhabits sub-tropical and tropical waters of the Americas and western Africa. Due to a lack of readily observable morphological variation in specimens across its range, the goliath grouper has been regarded as a single species. We tested the hypothesis that Pacific and West Atlantic populations constitute a single species by analyzing nuclear and mitochondrial DNA sequence data. We found numerous fixed genetic differences for mitochondrial loci between Pacific and West Atlantic goliath grouper (genetic distance $D \approx 3.5 \%$ at $16 \mathrm{~S}$ and $D \approx 6 \%$ at cytochrome $b_{;} \varphi_{\mathrm{st}}$ $=0.98[\mathrm{p}<0.001]$ for $16 \mathrm{~S}$ and $\varphi_{\mathrm{st}}=0.98[\mathrm{p}<0.001]$ for cytochrome $\left.b\right)$. The nuclear S7 intron showed 3 fixed nucleotide differences between Pacific and West Atlantic populations. Within the West Atlantic, we found few absolute genetic differences $(D<0.01$ at $16 \mathrm{~S}$ and $D<0.02$ at cytochrome $b)$, but statistically significant population structure based on haplotype frequency data $\left(\varphi_{\mathrm{st}}=0.04[\mathrm{p}=0.05]\right.$ at $16 \mathrm{~S}$; $\varphi_{\text {st }}=0.14[\mathrm{p}<0.001]$ at cytochrome $\left.b\right)$. These data indicate that (1) goliath grouper in the West Atlantic are subdivided into discrete populations, (2) goliath grouper populations in the Pacific and western Atlantic represent 2 (or more) distinct species, and (3) these distinct populations/species require separate management and conservation strategies. We resurrect the species Epinephelus quinquefasciatus (Bocourt 1868) for Pacific goliath grouper.
\end{abstract}

KEY WORDS: Epinephelus itajara · Epinephelus quinquefasciatus · Phylogeography · Epinephelidae Resale or republication not permitted without written consent of the publisher

\section{INTRODUCTION}

The number of species that exist on Earth is continually being revised and contested and is by no means a trivial consideration. It is generally believed that the stability and persistence of ecosystems is, in part, predicated on species richness (Reusch et al. 2005), and surveys aimed at compiling biodiversity inventories con- 
tinue to be at the forefront of conservation efforts. Surprisingly, this basic information is lacking in many areas, despite its obvious importance for conservation measures.

In the marine environment, biodiversity inventories often reflect the fact that marine species tend to be more broadly distributed than their terrestrial counterparts, with some organisms ranging more than $10000 \mathrm{~km}$ (Jablonski \& Lutz 1983). With the now widespread use of molecular genetic techniques, it has become clear that cryptic genetic diversity may confound estimates of both species ranges and biodiversity (reviewed in Bickford et al. 2006). Species once thought to be distributed over immense oceanic expanses are now known to be comprised of discreet lineages that may or may not occur in sympatry (reviewed in Rocha et al. 2007). Although this phenomenon was thought to occur most commonly in small or difficult-to-study organisms, recent evidence shows that these cryptic genetic lineages also occur amongst Earth's largest and most well-studied marine animals (e.g. Bass et al. 2005, Quattro et al. 2006, Vianna et al. 2006). In addition, these genetic studies often elucidate genetic patterns that reflect demographic connectivity, a critical aspect of population biology that is often unknown but imperative for effective conservation strategies.

The goliath grouper Epinephelus itajara (Epinephelidae) is one of the largest reef fishes on the planet, reaching over $2 \mathrm{~m}$ in length and nearly $450 \mathrm{~kg}$ in weight (Sadovy \& Eklund 1999). Although removed from the US NOAA Species of Concern list in 2006, goliath grouper are still regulated as a 'no take' species in the US. This high level of protection for the species has triggered an increase in juvenile goliath grouper in the southeastern US. However, goliath grouper populations are scarce throughout a majority of their range, and because of their shrinking numbers overall and the increasing threats they face, goliath grouper have been placed on the IUCN Redlist in the category 'Critically Endangered'. Placement of species in this category is reserved for the most threatened and impacted species on the planet, indicating an urgent need to increase our conservation efforts for this species.

Goliath grouper have a relatively large range for a marine fish, occurring in sub-tropical and tropical waters of the Pacific and Atlantic coasts of the Americas and West Africa (Heemstra \& Randall 1993). No morphological differences have been identified to date between these widely distributed populations, even between those that are separated by the most wellstudied and impassible biogeographic barrier, the Isthmus of Panama (Smith 1971, Heemstra \& Randall 1993, M. T. Craig unpubl. data). As a consequence, goliath grouper continues to be recognized as a single species across its range.
In an attempt to resolve the specific status of goliath grouper populations, we sampled goliath grouper from throughout its amphi-American range to test the hypothesis that these geographically disjunct populations are a single species using both nuclear and mitochondrial DNA sequences. We show that contrary to accepted taxonomy, amphi-American populations of goliath grouper are separated by a high degree of fixed genetic divergence that is on par with other morphologically identifiable species. Our data indicate that, despite the absence of a set of diagnosable morphological differences, the goliath grouper population in the eastern Pacific is best regarded as a separate and distinct species.

\section{MATERIALS AND METHODS}

Tissue samples of Epinephelus itajara were collected from 4 localities: Panama City, Panama (Pacific), Punta Gorda, Belize (Caribbean), Goodland, Florida, USA (Caribbean), and Caravelas, northeastern Brazil (West Atlantic). Three whole specimens from Panama were deposited as voucher specimens at the Scripps Institution of Oceanography Marine Vertebrates Collection (SIO 00-185). Several attempts were made to obtain specimens from West Africa, part of the historical range of E. itajara. None, however, were obtained, and an informal survey of fisherman from Mauritania, Senegal, Gambia, Guinea Bissau, Republic of Guinea and Sierra Leone revealed that few, if any, goliath grouper have been landed in those areas for some time ( $\sim 10 \mathrm{yr})$, indicating that it may be locally extinct in this part of its range (B. Seret \& J.-D. Durand pers. comm.). Tissues were taken from specimens captured by commercial and recreational fishermen at the collecting locality. Tissue samples were preserved in 95\% ethanol or sarcosyl-Urea and stored at ambient temperature in the laboratory. Total genomic DNA was isolated with the DNEasy isolation kit (Qiagen) following manufacturer's protocols. Extracted DNA was frozen in TE buffer and archived at $-20^{\circ} \mathrm{C}$. Polymerase chain reaction (PCR) was used to amplify an approximately 770 base pair (bp) fragment of the mitochondrial cytochrome $b(c y t b)$ gene and an approximately $590 \mathrm{bp}$ fragment of the $16 \mathrm{~S}$ rRNA gene. In order to evaluate the utility of nuclear loci, a subset of samples was screened at the nuclear S7 intron. Sample sizes for each gene and each population are listed in Table 1. For cyt $b$, initial amplification was carried out using universal primers designed by Song et al. (1998) and Taberlet et al. (1992). Only weak amplifications were attained, and species-specific primers were designed by eye to enhance amplification and sequencing. Primers used for all genes are listed in Table 2. PCR 
Table 1. Epinephelus itajara. Locations, sample sizes, and genetic diversity indices. $c y t b$ : cytochrome $b$

\begin{tabular}{|lccccc|}
\hline Gene/Site & N & $\begin{array}{c}\text { No. of } \\
\text { haplotypes }\end{array}$ & $\begin{array}{c}\text { No. of unique } \\
\text { haplotypes }\end{array}$ & $\begin{array}{c}\text { Haplotype } \\
\text { diversity }\end{array}$ & $\begin{array}{c}\text { Nucleotide } \\
\text { diversity }\end{array}$ \\
\hline $\mathbf{1 6 S}$ & & & & & \\
Panama & 25 & 3 & 3 & 0.156 & 0.0005 \\
Belize & 24 & 2 & 0 & 0.083 & 0.0001 \\
Brazil & 20 & 1 & 0 & 0.000 & 0.0000 \\
Florida & 30 & 4 & 2 & 0.303 & 0.0006 \\
cyt $\boldsymbol{b}$ & & & & & \\
Panama & 17 & 5 & 5 & 0.684 & 0.0013 \\
Belize & 23 & 4 & 4 & 0.525 & 0.0007 \\
Brazil & 18 & 5 & 2 & 0.601 & 0.0011 \\
Florida & 17 & 3 & & 0.324 & 0.0004 \\
S7 & & & 1 & & \\
Panama & 4 & 1 & 0 & 0.000 & 0.0000 \\
Belize & 4 & 1 & 0 & 0.000 & 0.0000 \\
Brazil & 5 & 1 & 0 & 0.000 & 0.00000 \\
Florida & 4 & 1 & & & \\
\hline
\end{tabular}

reaction mixes were prepared using BioMix Red (Bioline) following the manufacturer's instructions with the addition of $1 \mu \mathrm{M}$ of each primer for $c y t b$ and $10 \mu \mathrm{M}$ for $16 \mathrm{~S}$ and S7, and 10 to $100 \mathrm{ng}$ DNA template. The samples from Florida did not consistently amplify under the above conditions. Thus, $10 \mu \mathrm{l}$ reactions were prepared as follows: $67 \mathrm{mM}$ Tris- $\mathrm{HCl} \mathrm{pH} 8.8,16.6 \mathrm{mM}$ $\left(\mathrm{NH}_{4}\right)_{2} \mathrm{SO}_{4}, 10 \mathrm{mM} \beta$-mercaptoethanol, $2 \mathrm{mM} \mathrm{MgCl}{ }_{2}$, $800 \mu \mathrm{M}$ dNTPs, $0.5 \mu \mathrm{M}$ each primer, $0.5 \mathrm{mg} \mathrm{ml}^{-1} \mathrm{BSA}$, 0.5 units Taq DNA polymerase (New England Biolabs) and $0.5 \mu \mathrm{l}$ of stock DNA.

For the Panama, Belize, and Brazil samples, PCR reactions were carried out using an initial denaturing step at $94^{\circ} \mathrm{C}$ for $2 \mathrm{~min}$, followed by 35 cycles of amplification (30 s of denaturation at $94^{\circ} \mathrm{C}, 30 \mathrm{~s}$ of annealing at 48 to $50^{\circ} \mathrm{C}$, and $45 \mathrm{~s}$ of extension at $72^{\circ} \mathrm{C}$ ). For the Florida samples the following conditions were used: $92^{\circ} \mathrm{C}$ for $2 \mathrm{~min}$, followed by $45 \mathrm{cycles}$ of $92^{\circ} \mathrm{C}$ for $20 \mathrm{~s}, 52^{\circ} \mathrm{C}$ for $90 \mathrm{~s}, 72^{\circ} \mathrm{C}$ for $90 \mathrm{~s}$, and a final extension at $72^{\circ} \mathrm{C}$ for $3 \mathrm{~min}$. Excess oligonucleotide primers and dNTPs were removed by incubation with Exonuclease I and calf intestine alkaline phosphatase (ExoCIAP). Direct sequencing reactions with fluorescently labeled dideoxy terminators were performed according to the manufacturer's recommendations and analyzed with an ABI 3100 automated sequencer (Applied Biosystems) at the Hawaii Institute of Marine Biology Sequencing Core Facility. Unique haplotypes and intronsequences were deposited in GenBank (16S: EU445272-EU445279; cyt b: EU445280-EU445291, EU823101EU823103; S7: EU494944-EU494945).

Sequences for each gene were aligned using ClustalX (Thompson et al. 1997) and checked by eye. Phylogenetic hypotheses (trees) were constructed using PAUP*4.0b10 under distance, parsimony, and maximum likelihood optimality criteria. For all optimality criteria, default settings in PAUP were used. In the case of the maximum likelihood analysis, this corresponded to the HKY85 model of nucleotide substitution. In all cases, trees were rooted with Epinephelus fuscoguttatus. Branch support was assessed using bootstrap with 1000 replications. Sequences for outgroups were taken from GenBank for the species E. fuscoguttatus (AY947561.1) and E. lanceolatus (AY947588.1) for the 16S gene, and $E$. lanceolatus for cyt $b$ (DQ486927, DG486928, DQ372727). E. lanceolatus has been confirmed as the sister species to E. itajara by previous molecular and morphological analysis (Smith 1971, Craig \& Hastings 2007).

Population structure was assessed for both mitochondrial genes using Analysis of Molecular Variance (AMOVA) as implemented in the software package Arlequin (v.3.11; Excoffier et al. 2005). We first evaluated population structure using all sample locations, and then excluded those from Panama to assess population structure among Atlantic localities. Default settings in Arlequin were used for all AMOVA, with the exception that the Kimura 2 parameter model of nucleotide substitution was used in distance calculations.

Table 2. Sequencing and PCR primers used for mitochondrial and nucleardata analysis

\begin{tabular}{|llll|}
\hline Primer & Gene & Sequence & Source \\
\hline ItaCBF & cyt $b$ & 5'-CTACAAAAACCCTATCAATGACC-3' $^{\prime}$ & Present study \\
ItaCBR & cyt $b$ & $5^{\prime}$-GGTGAAGTTGTCTGGGTC-3' & Present study \\
16 SarL & 16S rRNA & $5^{\prime}$-CGCCTGTTTATCAAAAACAT-3' & Palumbi (1996) \\
16SbrH & 16S rRNA & $5^{\prime}$-CCGGTCTGAACTCAGATCACGT-3' & Palumbi (1996) \\
S7RPEX1F & S7 intron & $5^{\prime}$-TGGCCTCTTCCTTGGCCGTC-3' & Chow \& Hazama (1998) \\
S7RPEX2R & S7 intron & 5'-AGCGCCAAAATAGTGAAGCC-3' & Chow \& Hazama (1998) \\
\hline
\end{tabular}




\section{RESULTS}

Overall, we resolved $745 \mathrm{bp}$ of the cyt $b$ gene from 71 ind., $590 \mathrm{bp}$ of the 16S rDNA gene from 99 ind., and $651 \mathrm{bp}$ of the nuclear S7 intron from 13 ind. of goliath grouper. We found 15 haplotypes for cyt $b, 8$ haplotypes for 16S, and 2 alleles for S7. No haplotypes or alleles were shared between the Pacific Ocean (Panama) and Atlantic for any gene, and no indels were observed in any alignment. Within the West Atlantic, however, a single common haplotype was shared between Belize, Brazil and Florida for both cyt $b$ and $16 \mathrm{~S}$.

We found few absolute genetic differences (\% sequence divergence) between Atlantic sampling localities. However, we found several differences between Pacific and Atlantic populations. For the mitochondrial 16S gene there were 20 fixed nucleotide differences between Pacific and western Atlantic samples, while for $c y t b$ there were 41 , and 3 for the S7 intron. These putatively conspecific trans-isthmian populations represented reciprocally monophyletic clades with $100 \%$ bootstrap support when analyzed using distance, parsimony, and maximum likelihood tree-building algorithms (Fig. 1), and were separated by 3.36 to $3.69 \%$ divergence at the $16 \mathrm{~S}$ locus and 6.05 to $6.46 \%$ divergence at cyt $b$. Descriptive genetic statistics for each gene at each site are shown in Table 1.

Despite minimal genetic difference, AMOVA analyses indicated statistically significant genetic structure within the Atlantic. At cyt $b$ all sampling sites shared the most common haplotype; however, each site had 2 or more haplotypes that were restricted to

Fig. 1. Epinephelus spp. Phylogenetic tree based on the mitochondrial 16S rRNA gene. With the exception of tips, identical topology was obtained for cytochrome $b$ data. Tree is rooted with E. fuscogutattus (removed for clarity). Numbers above nodes are bootstrap supports ( $\mathrm{N}=1000$ reps). Locality abbreviations are: BRA $=$ Caravelas, Brazil; FLA = Florida, USA $;$ PG = Punta Gorda; Belize; PAN = Panama City, Panama. Sub.: substitutions

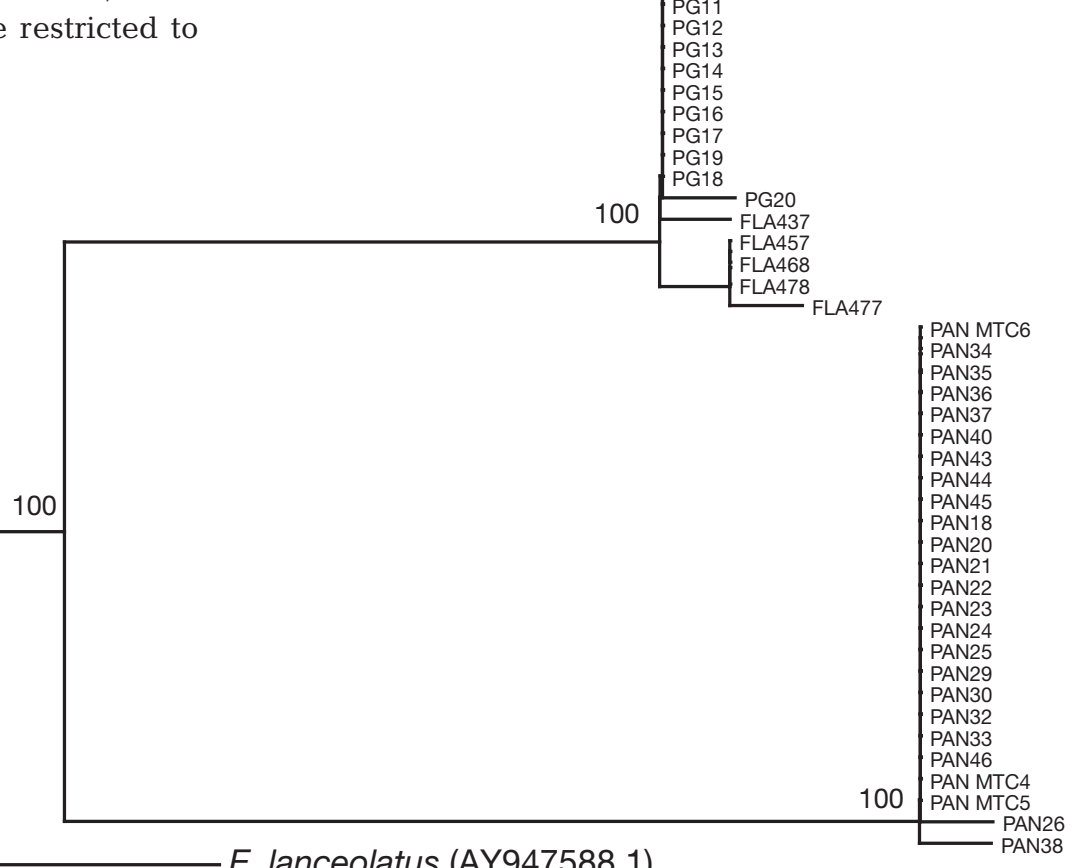


a particular locality (private haplotypes) and occurred in relatively high frequency (11 to $26 \%$ of the sample size). Among these populations at cyt $b \varphi_{\text {st }}=$ $0.14(\mathrm{p}<0.001)$ and at $16 \mathrm{~S} \varphi_{\mathrm{st}}=0.04(\mathrm{p}=0.05)$. When the Panama location was included, genetic structure was nearly fixed with $\varphi_{\text {st }}=0.97(\mathrm{p}<0.001)$ for cyt $b$ and $\varphi_{\mathrm{st}}=0.98(\mathrm{p}<0.001)$ for $16 \mathrm{~S}$. All pairwise comparisons of $\varphi_{\text {st }}$ were statistically significant (Table 3).

\section{DISCUSSION}

Uncovering hidden genetic partitions among organisms is one of the most important contributions that phylogeograhic and population genetic studies can provide for conservation efforts. Failure to recognize these cryptic partitions, which often reflect reduced demographic connectivity, can impact the way in which populations are managed (Rocha et al. 2007). In the marine environment, unforeseen genetic structure has been elucidated across enumerable taxa from rockfishes (Hyde et al. 2008) to copepods (Goetz 2003) to bryozoans (Davidson \& Haygood 1999). Our results add another layer to this complexity by adding an exceptionally large and well-studied marine fish to the list of genetically partitioned species.

\section{Atlantic population structure}

Unexpectedly, we found statistically significant population structuring within the western Atlantic. Our results demonstrate that, while goliath grouper share a large fraction of the total genetic diversity, there are unique haplotypes that are distributed more disproportionately than expected by chance. This pattern is clear for both the cyt $b$ data $\left(\varphi_{\mathrm{st}}=0.14, \mathrm{p}<0.001\right)$ and the more slowly evolving $16 \mathrm{~S}$ locus $\left(\varphi_{\text {st }}=0.04, \mathrm{p}=0.05\right)$. These results corroborate earlier genetic comparisons of Brazilian and US goliath grouper that identified divergent genetic signatures of a limited number of samples (Vaz-Perreira et al. 2007).

Table 3. Pairwise population $\varphi_{\text {st }}$ values (below diagonal) and corresponding $\mathrm{p}$ values (above diagonal). ${ }^{*}$ Significance at $\mathrm{p}=0.05$

\begin{tabular}{|lcccc|}
\hline & Panama & Brazil & Belize & Florida \\
\hline Panama & - & $<0.001^{*}$ & $<0.001^{*}$ & $<0.001^{*}$ \\
Brazil & 0.98 & - & $0.001^{*}$ & $0.021^{*}$ \\
Belize & 0.98 & 0.16 & - & $0.007^{*}$ \\
Florida & 0.98 & 0.08 & 0.15 & - \\
\hline
\end{tabular}

Belize and much of coastal Brazil are separated by a well-recognized biogeographic barrier to dispersal, the Amazon and Orinoco River outflows (sensu Briggs 1974 and discussed in Floeter et al. 2008). These freshwater systems essentially dilute typical saline conditions to the point where many marine taxa cannot survive. Goliath grouper, however, are known to recruit to brackish water conditions and spend several years in this habitat prior to an ontogenetic shift to reef habitat (Smith 1976, Frias-Torres 2006). Thus, we expected that goliath grouper should be able to tolerate conditions within the Amazon/Orinoco barrier and would be able to disperse across, if not live within, this barrier. Our results suggest that Brazilian and Caribbean goliath grouper populations are separate and distinct; however, the role of the Amazon/Orinoco outflow in shaping this structure is unclear given the biology of the species. No such barrier exists between Florida and Belize, however, and there is little to offer in terms of a physical explanation for the impaired gene flow shown by our data.

These results imply that goliath grouper should be managed as separate stocks throughout their Atlantic range. While the cyt $b$ gene is often considered to evolve at a sub-optimal rate for assessing contemporary gene flow, our data show a pattern that is consistent with the hypothesis that goliath grouper populations are not demographically connected. This is particularly evidenced by the presence of private haplotypes that occur at relatively high frequencies (up to $26 \%$ of the sample size at each site). A similar indication of discrete populations has been indicated between Florida and Belize based on analysis of variable microsatellite loci (R. Chapman pers. comm.), and thus we feel that the mtDNA data provide a reliable and concordant estimate of this structure. These results highlight the need for a directed stock analysis of goliath grouper, and ongoing efforts to increase sample sizes and locations, as well as to include more variable markers, will further enhance our understanding of the genetic connectivity within this species.

\section{Divergence times and speciation}

The amphi-American distribution of goliath grouper, coupled with the noted absence of morphological differentiation, provides a remarkable system to investigate the tempo of speciation in marine fishes. The Isthmus of Panama has provided a wealth of information regarding speciation mechanisms in the sea, and its role in shaping the biogeography and genetic architecture among goliath grouper is readily apparent. Fossil records indicate the presence of the immediate ancestor of goliath grouper from the upper Miocene that are 
virtually indistinguishable from extant species (Aguilera \& Rodrigues de Aguilera 2004). Goliath grouper, with their predilection for estuarine habitats as juveniles, represent one of the last marine fishes that would be expected to diverge during the gradual closing of the Isthmus of Panama (final closure approximately 3.2 million years (Myr); Coates \& Obando 1996). Using this date to calibrate a molecular clock results in a rate of $1.9-2.0 \%$ per Myr for cyt $b$ (range $D=6.0-6.5 \%$ uncorrected $\mathrm{p}$ ) and 1.0-1.1\% per Myr for 16S (range $D=3.4-3.7 \%$ uncorrected $\mathrm{p}$ ).

One potential cause for the lack of morphological difference between Pacific and Atlantic populations might be that they have not been separated for sufficient time in order for morphological evolution to occur. To address this, we compiled a list of epinephelid sister species for which genetic data are available and placed them in the context of geological time to establish when morphologically distinct species diverged (Table 4). Applying the molecular evolutionary rate above to the observed genetic difference between morphologically distinct epinephelid sister species confirms that transisthmian goliath grouper have had sufficient time for morphological divergence; the range of divergence estimates brackets that of goliath grouper. All sister species that were compared showed morphological differences ranging from subtle alterations of color pattern (e.g. Cephalopholis colonus and C. furcifer) to additional changes in fin-ray elements and other meristics (e.g. C. panamensis and C. cruentata).

\section{How many species of goliath grouper are there?}

While the biological species concept (sensu Mayr 1963) remains as one of the most accepted set of criteria for defining a species relying on actual or potential interbreeding, taxonomists have historically relied on one of several versions of the phylogenetic species concept, relying upon a set of diagnosable morphological characters (reviewed in Wheeler \& Meier 2000). These competing criteria have conspired to leave Pacific goliath grouper as an unrecognized, distinct species.

Trans-isthmian goliath grouper populations currently are reproductively isolated; the Isthmus of Panama physically prevents interbreeding. However, in the event of a sundering of this barrier, secondary contact between Pacific and Atlantic populations may prove that reproductive isolation has not occurred. (It should be noted that while some authors have suggested that goliath grouper may be able to traverse the Panama Canal [Heemstra \& Randall 1993], our results do not support this; even though the canal has been open for a relatively short period of time, shared haplotypes would be expected if juveniles were traversing this freshwater system). Simultaneously, the absence of diagnosable morphology argues that these are truly populations of one species.

Prior to the present study, regarding goliath grouper populations as distinct species was not a favored strategy, as to do so would have relied on a species concept born out of convenience: the 'geopolitical species concept' (sensu Karl \& Bowen 1999). Geopolitical species are defined as:

...groups of individuals [that are] confined to geographically or politically defined areas and [that] are accorded species status independent of morphological, genetic, and reproductive criteria. (Karl \& Bowen 1999, p. 996)

However, in light of the present data, we now have a diagnosable set of nucleotide characters and an expectation of reproductive isolation that has been maintained for millions of years to continue for a considerably long future, both of which provide evidence that these populations are moving along independent evolutionary trajectories and should be recognized independently (sensu Ryder 1986, Moritz 1994, Eizirik

Table 4. Genetic distances (uncorrected p) and estimated divergence times for sister species of grouper. Data from Craig et al. (2004) and Craig \& Hastings (2007). Atl: Atlantic; Pac: Pacific. Myr: million years; kyr: kilo year; -: no data available

\begin{tabular}{|c|c|c|c|c|}
\hline \multirow{2}{*}{ Species pair } & \multicolumn{2}{|c|}{$-16 \mathrm{~S} \longrightarrow$} & \multirow[b]{2}{*}{$\begin{array}{l}\text { \% sequence } \\
\text { divergence }\end{array}$} & \multirow{2}{*}{$\begin{array}{c}\text { cyt } b \text { Divergence } \\
\text { time }\end{array}$} \\
\hline & $\begin{array}{l}\% \text { sequence } \\
\text { divergence }\end{array}$ & $\begin{array}{l}\text { Divergence } \\
\text { time }\end{array}$ & & \\
\hline Alphestes immaculatus/A. multigutattus & 3.0 & $2.7 \mathrm{Myr}$ & 6.9 & 3.5 Myr \\
\hline Cephalopholis cruentatus/C. panamensis & 2.5 & $2.2 \mathrm{Myr}$ & - & - \\
\hline Cephalopholis colonus/C. furcifur & 2.2 & $2.0 \mathrm{Myr}$ & - & - \\
\hline Dermatolepis inermis/D. striolata & 1.2 & 1.0 Myr & 7.4 & $3.7 \mathrm{Myr}$ \\
\hline Epinephelus clippertonensis/E. labriformis & 0.0 & $<10 \mathrm{kyr}$ & $0.0-0.5$ & $<10$ kyr \\
\hline Epinephelus itajara (Pac)/E. itajara (Atl) & 3.5 & $2.9 \mathrm{Myr}$ & 6.0 & $3.0 \mathrm{Myr}$ \\
\hline Epinephelus lanceolatus/E. itajara (Pac) & 3.9 & $3.5 \mathrm{Myr}$ & 11.0 & 5.5 Myr \\
\hline Epinephelus lanceolatus/E. itajara (Atl) & 3.5 & $2.9 \mathrm{Myr}$ & 11.0 & 5.5 Myr \\
\hline Hyporthodus nigritus/H. exsul & 3.5 & $2.9 \mathrm{Myr}$ & - & - \\
\hline
\end{tabular}


1996). It is thus clear that Pacific and Atlantic goliath grouper represent 2 distinct species.

The resolution for the taxonomic status of goliath grouper species is relatively straightforward. The type locality for Epinephelus itajara (Lichtenstein 1822) is Brazil (holotype, as Serranus itajara, ZMB 238), and thus the Atlantic populations would retain this name with priority. The oldest available name for an eastern Pacific population is E. quinquefasciatus (Bocourt 1868) (type locality Pacific coast of Guatemala; holotype, as $S$. quinquefasciatus, MNHN 0000-5211). It is thus our recommendation, following the rules of the International Commission on Zoological Nomenclature (ICZN), that this name be applied to Pacific populations of goliath grouper. We suggest common names of Atlantic goliath grouper and Pacific goliath grouper, respectively.

\section{Underestimating biodiversity}

The use of traditional species concepts in the documentation of Earth's biodiversity remains pervasive among common practices. For all practical purposes, the primary criterion for determining what is or is not a species is morphological distinctiveness. The lack of attention to the contribution that genetic diversity makes to overall biodiversity estimates has recently been highlighted as a potential pitfall of current methods (reviewed in Bickford et al. 2006). Our results echo earlier cautions that cryptic genetic lineages may confound our ability to adequately estimate biodiversity (e.g. Fukami et al. 2004) and also add another caution: large organisms cannot be ignored in this regard. Our data, along with other recent studies (e.g. Bass et al. 2005, Quattro et al. 2006, Vianna et al. 2006) clearly show that the phenomenon of hidden genetic divergence is not restricted to understudied or difficult-tostudy organisms, as has been the basis of conventional wisdom. In fact, goliath grouper are at the forefront of conservation efforts, as is evidenced by their presence as the focus of recent symposia, their listing by the IUCN as 'Critically Endangered,' their prior listing as a species of concern in US waters by US Fish and Wildlife Service, and a moratorium on their capture in both Brazil and the US.

\section{CONCLUSIONS}

While the goliath grouper has been recognized as a single, broadly distributed species, our data clearly show that this is not the case. We have shown that there are at least 2 species of goliath grouper, one in the Pacific (now treated as Epinephelus quinquefascia- tus [Bocourt]) and one in the Atlantic (E. itajara [Lichtenstein]), and that there are discrete populations in the Atlantic. The taxonomic status of eastern Atlantic goliath grouper is unknown, but best treated as E. itajara until - or possibly if - more evidence is brought to light.

There is now the opportunity to evaluate each of these species independently in terms of its potential risk for extinction following IUCN criteria, as well as the opportunity to develop more realistic conservation measures for these important marine species. Given the noted decline in goliath grouper throughout its range (in particular the absence of the largest individuals once known to be common; L. McClenachan 2009, this Theme Section), this is not a trivial task. The absence of goliath grouper from the West African fishery coupled with its uncertain taxonomic status may be a harbinger of extinction; just as David, we may have slain an oceanic Goliath.

Acknowledgements. This work was partially funded by Petrobras S/A (Programa Petrobras Ambiental) and Conservation International Brazil to Projeto Meros do Brasil (www.merosdobrasil.org), The Summit Foundation to the Belize goliath grouper project, and the National Science Foundation (grant nos. OCE-0454873 and EPS-0554657). M.T.C was supported by the HIMB-NWHI Coral Reef Research Partnership during the course of this research (NMSP MOA 2005-008/66882). We are grateful to B. Bowen, S. Karl and L. Rocha for thoughtful discussion and comments on earlier versions of this manuscript. We thank H. J. Walker and C. Klepadlo, SIO Marine Vertebrates Collection for curatorial assistance. This is SOEST contribution no. 7311 and HIMB contribution no. 1304.

\section{LITERATURE CITED}

Aguilera O, Rodrigues de Aguilera D (2004) Goliath grouper (Pisces: Serranidae) from the upper Miocene Urumaco formation, Venezuela. J Paleontol 78:1202-1206

Bass AL, Dewar H, Thys T, Streelman JT, Karl SA (2005) Evolutionary divergence among lineages of the ocean sunfish family, Molidae (Tetraodontiformes). Mar Biol 148:405-414

Bickford D, Lohman DJ, Sodhi NS, Ng PKL and others (2006) Cryptic species as a window on diversity and conservation. Trends Ecol Evol 22:149-155

Briggs JC (1974) Marine zoogeography. McGraw Hill, New York

> Chow S, Hazama K (1998) Universal PCR primers for S7 ribosomal protein gene introns in fish. Mol Ecol 7: $1255-1256$

Coates AG, Obando JA (1996) The geologic evolution of the Central American Isthmus. In: Jackson J, Budd AF, Coates AG (eds) Evolution and environment in tropical America. The University of Chicago Press, Chicago, IL, p 21-56

Craig MT, Hastings PA (2007) A molecular phylogeny of the groupers of the subfamily Epinephelinae (Serranidae) with a revised classification of the Epinephelini. Ichthyol Res 54:1-17

Craig MT, Hastings PA, Pondella DJ II (2004) Speciation in the Central American Seaway: the importance of taxon 
sampling in the identification of trans-isthmian species pairs. J Biogeogr 31:1085-1091

Davidson SK, Haygood MG (1999) Identification of sibling species of the bryozoan Bugula neritina that produce different anticancer bryostatins and harbor distinct strains of the bacterial symbiont 'Candidatus endobugula sertula'. Biol Bull 196:273-280

Eizirik E (1996) Ecologia molecular, genética da conservação e o conceito das unidades evolutivamente significativas. Braz J Genet 19(Suppl):23-29

Excoffier L, Laval G, Schneider S (2005) Arlequin ver. 3.0: an integrated software package for population genetics data analysis. Evol Bioinform Online 1:47-50

Floeter SR, Rocha LA, Robertson DR, Joyeux JC and others (2008) Atlantic reef fish biogeography and evolution. J Biogeogr 35:22-47

Frias-Torres S (2006) Habitat use of juvenile goliath grouper Epinephelus itajara in the Florida Keys, USA. Endang Species Res 2:1-6

Fukami H, Budd AF, Paulay G, Sole-Cava A, Chen CLA, Knowlton N (2004) Conventional taxonomy obscures deep divergence between Pacific and Atlantic corals. Nature 427:832-835

Goetze E (2003) Cryptic speciation on the high seas; global phylogenetics of the copepod family Eucalanidae. Proc R Soc Lond B Biol Sci 270:2321-2331

Heemstra PC, Randall JE (1993) Groupers of the world. FAO Species Catalogue 16, Rome

Hyde JR, Kimbrell A, Budrick JE, Lynn EA, Vetter RD (2008) Cryptic speciation in the vermilion rockfish (Sebastes minatus) and the role of bathymetry in the speciation process. Mol Ecol 17:1122-1136

Jablonski D, Lutz RA (1983) Larval ecology of marine benthic invertebrates: paleobiological implications. Biol Rev 58: 21-89

Karl SA, Bowen BW (1999) Evolutionary significant units versus geopolitical taxonomy: molecular systematics of an endangered sea turtle (genus Chelonia). Conserv Biol 13:990-999

Mayr E (1963) Animal species and evolution. Harvard University Press, Cambridge, MA

McClenachan L (2009) Historical declines of goliath grouper populations in South Florida, USA. Endang Species Res 7:175-181

Moritz C (1994) Defining 'Evolutionarily Significant' units for conservation. Trends Ecol Evol 9:373-375

Palumbi SR (1996) Nucleic acids II: the polymerase chain

Editorial responsibility: Kevin Rhodes,

Hilo, Hawaii, USA reaction. In: Hillis DM, Moritz C, Mable BK (eds) Molecular systematics. Sinauer, Sunderland, MA, p 205-248

Quattro JM, Stoner DS, Driggers WB, Anderson CA and others (2006) Genetic evidence of cryptic speciation within hammerhead sharks (Genus Sphyrna). Mar Biol 148: 1143-1155

Reusch TBH, Ehlers A, Hämmerli A, Worm B (2005) Ecosystem recovery after climatic extremes enhanced by gentypic diversity. Proc Natl Acad Sci USA 102:2826-2831

Rocha LA, Craig MT, Bowen BW (2007) Phylogeography and the conservation of coral reef fishes. Coral Reefs 26: 501-512

> Ryder OA (1986) Species conservation and systematics: the dilemma of subspecies. Trends Ecol Evol 1:9-10

Sadovy Y, Eklund AM (1999) Synopsis of biological data on the Nassau grouper, Epinephelus striatus (Bloch 1792) and the jewfish E. itajara (Lichtenstein 1822). NOAA Tech Rep NMFS 146. US Department of Commerce, Seattle, WA

Smith CL (1971) A revision of the American groupers: Epinephelus and allied genera. Bull Am Mus Nat Hist 146:1-241

Smith GB (1976) Ecology and distribution of eastern Gulf of Mexico reef fishes. Fla Mar Res Inst Publ 19:1-78

Song CB, Near TJ, Page JM (1998) Phylogenetic relations among percid fishes as inferred from mitochondrial cytochrome $b$ DNA sequence data. Mol Phylogenet Evol 10:343-353

Taberlet P, Meyer A, Bouvet J (1992) Unusually large mitochondrial variation in populations of the blue tit, Parus caeruleus. Mol Ecol 1:27-36

Thompson JD, Gibson TJ, Plewniak F, Jeanmougin F, Higgins DG (1997) The ClustalX windows interface: flexible strategies for multiple sequence alignment aided by quality analysis tools. Nucleic Acids Res 25:4876-4882

Vaz-Perreira R, Torres RA, Freitas M, Gerhardinger LC, Hostim M (2007) Prospecção genômica (mtDNA) para ‘barcoding taxonomy' em espécies da família Serranidae (Actinopterygii: Perciformes): buscando a identidade genética de Epinephelus itajara (Mero). Proc XVII Encontro Brasileiro de Ictiologia, p 540

> Vianna JA, Bonde RK, Caballero S, Giraldo JP and others (2006) Phylogeography, phylogeny and hybridization in trichechid sirenians: implications for manatee conservation. Mol Ecol 15:433-437

Wheeler QD, Meier R (2000) Species concepts and phylogenetic theory: a debate. Columbia University Press, New York

Submitted: February 19, 2008; Accepted: June 29, 2008

Proofs received from author(s): August 7, 2008 